University of Nebraska - Lincoln

DigitalCommons@University of Nebraska - Lincoln

Space, Cyber, and Telecommunications Law

Program Faculty Publications

2019

Legal Challenges in the Context of the European Space Policy

Frans von der Dunk

Follow this and additional works at: https://digitalcommons.unl.edu/spacelaw

Part of the Air and Space Law Commons, Comparative and Foreign Law Commons, International Law Commons, Military, War, and Peace Commons, National Security Law Commons, and the Science and Technology Law Commons

This Article is brought to you for free and open access by the Law, College of at DigitalCommons@University of Nebraska - Lincoln. It has been accepted for inclusion in Space, Cyber, and Telecommunications Law Program Faculty Publications by an authorized administrator of DigitalCommons@University of Nebraska - Lincoln. 
Published as chapter 4 in A European Space Policy: Past Consolidation, Present Challenges and Future Perspectives, edited by Thomas Hoerber and Sarah Lieberman, Space Power and Politics Series, London: Routledge/Taylor \& Francis Group, 2019.

Copyright (c) 2019 Frans G. von der Dunk. Used by permission.

Chapter 4

\title{
Legal Challenges in the Context of the European Space Policy
}

\author{
Frans von der Dunk
}

\section{Introduction}

If institutionalism is about the extent to which institutions influence the political and legal realms, and (political) neoinstitutionalism in that respect stresses the extent to which decisions by political actors are framed by institutions, European space policy would present a very interesting example thereof (Senge, 2006: 42).

It should be noted, however, that this contribution addresses the issue of European space policy from a predominantly legal vantage point, not that of political science, meaning that even such concepts as "policy" and "institution" are first and foremost being discussed in their legal connotation and context, read from the perspective of a lawyer. Such a vantage point certainly also determines the extent to which the analysis undertaken will shed light on the theory of "neoinstitutionalism," a political-science theory focusing on the role and nature of institutions as "collections of interrelated rules and routines that define appropriate actions in terms of relations between roles and situations" (March and Olsen, 1989: 162).

From the-in this respect narrower-legal perspective, only institutions of the wellelaborate, structured, and substantive kind, with personnel, buildings, and money at their disposal are relevant. "Weak" social drivers such as social manners, customs, and resulting behavior might still be seen as such "collections of interrelated rules and routines," yet from a legal vantage point at best may exercise some background influence, being unable to directly establish law or be directly subjected to it (Senge and Hellmann, 2006: 27, 36, 44, 46). 
Certainly, in the context of European space policy as it is addressed here, there is a sufficient number of the "strong" brand of institutions playing key roles for the present article not to go into much detail into the "weaker" ones; it is the totality of these "stronger" institutions, "true" institutions from the legal perspective, which serve as a filter of a range of policy choices in a close and complex interrelationship with the law (Senge and Hellmann, 2006: 44, 93). After all, from the other end such institutions, due to their formal nature, size, importance, and stability, are almost invariably a product of law-international organizations of treaties, national organizations of constitutions, laws, regulations, statutes or charters.

Already, however, the mere notion of a "European space policy" raises a number of questions as to which institutions are playing which key roles in its context, both at the European level itself and at the level of the individual Member States. Thus, this chapter will focus on the way in which a European space policy, as the idea has been developed over the last few decades, has been addressed by way of efforts to elaborate and implement it in the legal arena and how it has been given some shape or form using existing institutions and existing law, respectively, by developing new institutions and/or law. Given the complexity of the matter, it is important at the outset to precisely determine the key concepts of, and main parameters for, such an analysis: which "Europe" are we addressing, and how do the twin notions of "institutions" and "law" work together in that particular environment to result in something which-perhaps - could be called a "space policy"?

\section{Of "policy," "institutions," and "law": some initial considerations}

Policy is a concept which can be defined in a very broad manner as "a plan of action adopted by, for example, an individual, group, business or government" (Heywood, 2007: 426) or more specifically as "the supreme instrument of power in politics" (Daviter, 2011: 26). What is most important from a legal perspective, however, in particular if one is to understand the complex, partly overlapping, partly diverging concepts of "policy" and "law" in relation to each other, is that "policy" should be seen as a relatively conscious and focused approach to a certain set of situations, scenarios, and/or developments in today's complex societies, usually driven by an overarching aim or objective of an either moral/ philosophical (including religious) or more pragmatic nature-or any conceivable mix thereof. In essence, policy itself thus is theoretical; as such it exists on paper only but is then supposed to give rise to certain decisions, practices, and actions, and it is also flexible.

Following such a definition, space policy should refer to a set of ideas or plan on how to use outer space and space activities for the benefit of the respective communities represented by the policy makers, prioritizing certain kinds of space activities and embodying efforts to curb potentially negative effects of such activities, whether conducted by the relevant community and/or their policy makers or by others active in the field. Space policy thereby would also almost automatically represent an implementation or demonstration of power in the field (Daviter, 2011: 26).

European space policy, more specifically again, refers to a space policy developed at the level of Europe, its exact boundaries defined by the institutional framework in which the 
decision was made, maintained, promoted, and implemented (Hoerber and Stephenson, 2016: Conclusion). ${ }^{1}$

As already indicated, a complicated relationship exists between the key concept of "policy" and those of "institutions" and "law," not just in Europe but elsewhere as well-even as Europe tends to present a particularly interesting manifestation of these complex relations, with the European Space Agency and the European Union as the most visible and influential institutions playing a key role in this regard.

Parl of that complexity, of course, resides in that of institutionalism as such, as also viewed from a political science perspective, where definitions of institutions "fall well short of a comprehensive theory" (Hoerber and Lieberman, 2019: Introduction). Indeed, it has been noted that the lack of definition may even be considered a "hallmark" (albeit one among other hallmarks) "of neoinstitutionalism," a framework which "has major gaps in its self-conception" (Hoerber and Lieberman, 2019: Introduction).

From the legal perspective, more importantly, the brand of "strong" institutions involved in European space policy is characterized as often being established and maintained to develop and/or implement policies, as they provide a structured and quasi-stable tool that allows for a more gradual and consistent development and implementation thereof. These kinds of institutions, after all, usually employ paid officials with specific mandates and tasks, have elaborated financial structures in place to pay for their activities, and often even buildings and other hardware to complement those, all allowing on a quasipermanent basis the undertaking or stimulation of activities in implementation of relevant policies.

At the same time, of course, vice versa institutions are also often the result of an initial, usually at that stage more abstract, policy or policy approach and established for the very purpose of making such a policy or policy approach work, or at least work more effectively. Once a particular policy is considered important enough, most likely its proponents would urge for and/or work toward the establishment of an institution in the earlier sense of the word precisely in order to enhance the chances of that policy becoming successfully implemented. The history of postwar Europe provides some of the most explicit, extended, and important examples thereof: out of the general policy "never again another World War in Europe" quickly grew the many institutions trying to integrate former enemies precisely for that purpose: the Council of Europe, the Western European Union, and of course the three Communities that later evolved into the European Union (von der Dunk, 2010, 2015 : 205). As we shall see, the same applies to the European efforts in space as well.

In other words, legal literature tells us that the conceptual relationship between "policies" and "institutions" is bidirectional: policies often drive the establishment of institutions, institutions in turn often drive the implementation and further development of policies. In this respect, any approach suggesting that the relationship between policy (makers) and institutions is of a one-way character, with institutions changing policy actors but policy actors not able to change institutions, would seem to be fundamentally flawed (Hasse and Krücken, 1999: 21). Institutions do not grow as trees in nature, thus to be taken as faits accomplis; they are formally established for a policy-driven reason-and then continue to play certain, sometimes self-propelled roles in that policy context.

On the other hand, not all policies give rise to institutions or make use exclusively of those; neither do all institutions serve only as tools for policy-policies are by their nature 
fluid, flexible, and versatile (and, as said, essentially existing on paper), and institutions are by their nature more rigid, inflexible, and often unwieldy (and normally existing in visible and tangible forms, such as personnel, buildings, and funds).

A similar analysis from a legal angle seems to hold with regard to the relationship between policy and law at this level of abstraction: as we shall see, while the latter is, like the former and unlike institutions, essentially of an intangible nature, visible only to the extent of being expressed on paper, it is conversely (relatively) rigid and inflexible, and at times also unwieldy. This obviously leaves aside the phenomenon that law can give rise to tangible items in many ways.

Here, it is to be noted that policy can be expressed in many ways. Policy can of course be made, alternatively pronounced by oral statements picked up by the media, of whoever is in charge of such a policy. While oral statements as such occasionally could also come to express law, this requires additional elements of a formal nature, such as the official nature, character, and selling thereof. Policy can of course also be made, alternatively pronounced in writing - and while most law indeed is of a written nature, again the formal elements, including the usually complex processes of arriving at the text, distinguish written law from written policy. More uniquely, however, policy can also be made without any explicit announcement as such, simply by doing something, such as financing particular activities, that is in more indirect, semiconscious, and inconspicuous ways - for law, it is normally impossible to be made in such an indirect manner. In the reality of policy making, of course, any feasible combination of oral statements, written statements, and actions would be used.

In each case, the major distinction between "policy" and "law" as concepts concerns the flexibility of the former. From a legal perspective, the most distinctive trait of policy is that a previous policy or policy-action can often be replaced, even "overruled" by the next one relatively easily; sometimes a mere change of mind with the personalities at the helm of a government or ministry may do. Often, there is no inherent formal mechanism dictating how one policy would succeed or supersede the other, and there is certainly no inherent reason why a particular policy could not be overhauled the next day-only pragmatic and political reasons. In that sense, "policy" is indeed a relatively informal and flexible tool for societies to address relevant situations, to prepare for relevant scenarios, and to direct or guide relevant developments. Also here, in reality, policies cover a wide spectrum: some are so much a whim that they maybe do not even deserve being labeled "policy," others are so strictly and formally elaborated that the dividing line with law becomes blurred. Nevertheless, the core feature of "policy" as compared to "law" is its lack of principled, overarching formality.

From that perspective, the concept of a European space policy would refer to any statement, whether oral, written, or through action, of someone somehow entitled to speak on behalf of "Europe" (notably, following our further discussion, the European Space Agency and/or the European Union), providing an overall idea as to where the European space endeavor, or substantive segments or elements of it should go, possibly backing this up with financing proposals or decisions and/or further instruments not as informal as policies.

By contrast or course, as argued, "law" is a formal and, as a consequence, also relatively rigid and stable tool for societies to address situations, prepare for scenarios, and direct developments. It can be expressed only through almost standardized and specifically 
formatted "statements" such as treaties, conventions, and something called customary law on the international level (Cassese, 2001; Lepard, 2017: 12, 31-33), ${ }^{2}$ and constitutions, laws, statutes, and regulations on the national level-which sometimes serve to elaborate and implement obligations resting upon a particular state pursuant to international law (Cassese, 2001: 162-181; Wallace, 1997: 35-58).

Once policy becomes law, even if it is subject to doubt and/or debate as to its precise contents and scope, in principle it is binding upon whomever it is directed to (in accordance with predetermined legal principles and concepts), can be invoked before courts and arbitral tribunals and then enforced by those institutions bestowed with executive powers, and can be changed only by formalized processes (often also involving specific, well-defined institutions) that broadly speaking are part of the law itself. Without becoming law, policy in itself can achieve none of those things.

Changing the law while disregarding these formalized processes effectively equates with revolution. Although there is increasing discussion nowadays among international lawyers about something called "soft law" (Marboe, 2012), the baseline simple dichotomy is still that something is either law and legally binding, or it is not-in which case it may well have morally and/or politically binding force but cannot be invoked before a court of arbitral tribunal.

As a consequence, the relationship between policy and law is also in many ways bidirectional. Many policies will drive particular legislative developments, as the establishment of law to underpin a certain policy or policy approach provides more stability and strength to the policy and its ultimate goals. Once a major policy has been translated into law, it becomes so much more difficult to change it-precisely because of the relative inflexibility of the law and the need to go through formalized processes before changes can occur. Actually, most law may be said to have come about pursuant to certain prior policies or policy approaches, including, at the highest level, moral, religious, philosophical, or more pragmatic considerations.

Vice versa, however, for precisely those reasons, once there is law with regard to certain situations, scenarios, and developments, it has an autonomous force of its own: it may not only enhance preceding policies, it may also direct and determine the latitude for new policies or the implementation of existing ones. If policies fundamentally are seen to go outside of what is permissible by existing law, they will either be addressed as criminal-or, in hindsight, be legitimized following a revolution which has overhauled the basic legal system as such.

Again, the relationship is not all-encompassing. Many elements of law are not dictated by a particular explicit policy but have come about as the consequence of practical solutions or developments in the real world as such, which at some point congealed into something called "customary law" and was formally confirmed as such by courts. From the other end, as said, not all policies find their way into specific law-many policy initiatives translate into paying for something or otherwise stimulating and facilitating it rather than imposing prohibitions or allocating rights.

In short, "law" - which once again from this perspective includes institutions established by law-comprises a relatively rigid as well as stable tool in societies to both underpin and strengthen certain policies and provide limits to what certain policies can do. In 
any domain with an abundance of political and legal institutions and other actors trying to promote their own interests through policies (of which Europe certainly is a prime example), law plays a key role in providing for a sound, solid, and predictable common ground outside of which none of such policies are supposed to move. The law ensures - at least in theory - that all policies and policy options that are executed at least respect certain common boundaries and common understandings, so that in that sense it guarantees a certain commonality and community.

Ultimately, whether the balance between the flexibility of policy and the stability of law (and institutions) is struck correctly may well be a matter of moral, religious, philosophical and/or political perspective. As we shall see in the next paragraph, Europe is a particularly interesting area from this perspective, as it is awash in policies and institutions dealing with space activities at both the national and the overarching European level. Consequently, the development of a space policy and the underpinning space law certainly has its additional challenges compared to single-country space powers.

\section{Of "Europe": a crash course in the history of the European space endeavor}

In Europe, almost as soon as the space age commenced, various stakeholders emerged keen to make a substantial impact on the human space endeavor-and not just at the national level. For obvious historical reasons, especially the United Kingdom and France were quick in trying to develop military space capabilities at a national level, and France, in addition, established its national space agency Centre national d'études spatiales (CNES) as early as 1961 (JO, 1961: 11665). While other countries were keen from the start to develop a presence in space activities mainly or exclusively through cooperation with other European countries, even those two countries realized that without European collaboration they would most likely never be able to develop all-encompassing space programs.

Thus, in 1962, two international treaties were signed giving rise to the formal establishment by 1964 of two collaborative European space institutions, the European Launcher Development Organization (ELDO, 1964) and the European Space Research Organization (ESRO, 1964). They presented the first joint institutionalization of the space policies of the respective Member States, which recognized the potential of pooling material resources and technical know-how and thereby the added value of European collaboration for their individual national space policies (even if not always clearly articulated). It was part of the individual space policies of the respective Member States to recognize that combining resources through European institutions created by treaty law would enhance the benefits space activities in general could bring to their respective societies.

The individuality of those policies was inter alia reflected by the fact that ELDO and ESRO did not have identical membership; some countries were from a clearly national policy perspective interested only in participating in the one or the other. Even more telling, the majority of European states did not join either of them-whether out of general disinterest in space activities or because of being part of the Warsaw Pact; in that sense the word "European" in the name of both organizations merely reflected the potential membership ${ }^{3}$ rather than any claim to representing all of Europe. In reality, of course, membership remained confined to Western European countries - and not even all of those at that. 
At the (Western-)European level itself, ELDO and ESRO being uniquely geared toward joint space projects, if there was something like an "ELDO space policy" or an "ESRO space policy," it amounted to the common denominator of the individual Member States' policies as expressed, rather $a d$ hoc, to some extent inconsistent and ultimately implicitly, by the various concrete programs and projects agreed upon within the two organizations by their respective sets of Member States. By no means did ELDO or ESRO wield any independent authority to decide on space programs or space projects against the wish of any particular member state. Even less were these two organizations entitled to draft any overarching space policy that would explicitly and unmistakably be presented as such, and which would then forcefully determine and direct such programs and projects. Any space policy that could be discerned at the level of the organizations remained fairly abstract, vaguely shaped, and general in nature-that is, nothing more concrete than that joining efforts to create a European launch sector respectively a European space science community was in the interest of the participating Member States-and still subject to the agreement of the Member States in any event.

ESRO and ELDO for reasons recounted elsewhere in great detail (Madders, 1997; Lafferranderie, 2005) in the end were considered insufficiently effective in promoting the interests and policies of their individual membership, and the two organizations were merged into the European Space Agency (ESA) as of 1975 (formally as of 1980). ${ }^{4}$

While further along this chapter will address the issue in greater detail, certainly initially this conclusion continued to hold true also for the new organization. Any statement, document, or activity coming out of ESA that could be considered part of or relevant to the issue of a space policy at the ESA level ultimately depended upon the consent of the ESA Member States. Such consent was either general in nature and given a priori as expressed through the ESA Convention, or it was specific to particular space programs and projects as developed based on that Convention. There certainly was no legal obstacle whatsoever for individual Member States to continue or develop their own national space policies, programs, and agencies, let alone laws and regulations. In particular, the larger European states (France, the United Kingdom, [at the time West-] Germany, Italy, and Spain) continued to develop and operate quite extensive national space programs, which alongside their participation in ESA were ultimately driven by national space policies reflecting national interests and priorities in terms of space.

While ESA henceforth was considered the primary embodiment of "Europe in Space," it would furthermore by no means be the only one. Following successful experiments with communication satellite technology, in 1982 (formalized in 1985) EUTELSAT, the European Telecommunications Satellite Organization, was established to maintain and operate a European satellite communications system (von der Dunk, 2015: 232-236; Madders, 1997: 504-514). ${ }^{5}$ Likewise in 1983 (formalized in 1986) EUMETSAT, the European Organization for the Exploitation of Meteorological Satellites, was established to operate a pan-European weather satellite system (von der Dunk, 2015: 236-238; Madders, 1997: 516-520). ${ }^{6}$ Casting the net wider still, the launch service provider Arianespace, established in 1980, was also part of this development. Although legally a private company of French nationality, due to the intricate involvement of ESA and its Member States in its structure and operations, Arianespace could be considered a representation of "Europe" in space as well (von der 
Dunk, 2015: 228-232; Madders, 1997: 520-526). Even the erstwhile Western European Union (WEU) at some point had its own satellite operations center at Torrejon (von der Dunk, 2010: 85). ${ }^{7}$ Clearly, such international institutions based on specific treaties were seen as a prime tool for the respective individual Member States participating in them to promote and enhance the effective implementation of their national space policies.

At least until 1985, ESA represented the main institutionalization of European cooperation in outer space and as such the main embodiment of the European space endeavor. Hence, to the extent one could speak of a space policy as a conscious and focused "set of ideas or a plan of what to do in particular situations that has been agreed to officially by a group of people, a business organization, a government, or a political party" (Cambridge Dictionary, 2018), ESA merely served as the most visible reflection of any European space policy. Before we go into the paradigm changes taking place following 1985, however, we should briefly go into some details regarding the way any space policies were actually given shape through ESA, read how this institution became a legal foundation for such policies.

\section{The role of ESA in space activities: a formalized and institutionalized framework}

The overarching purpose of establishing ESA was expressed by the ESA Convention, originally signed and ratified by ten but meanwhile by 22 Member States (all European ${ }^{8}$ ), as follows:

The purpose of the Agency shall be to provide for and to promote, for exclusively peaceful purposes, cooperation among European States in space research and technology and their space applications, with a view to their being used for scientific purposes and for operational space applications systems,

a) by elaborating and implementing a long-term European space policy, by recommending space objectives to the Member States, and by concerting the policies of the Member States with respect to other national and international organizations and institutions;

b) by elaborating and implementing activities and programmes in the space field;

c) by coordinating the European space programme and national programmes, and by integrating the latter progressively and as completely as possible into the European space programme, in particular as regards the development of applications satellites;

d) by elaborating and implementing the industrial policy appropriate to its programme and by recommending a coherent industrial policy to the Member States (ESA, 1980: Art. 11 [ emphasis added]).

Thus, while the Convention prominently urged for a European space policy to be elaborated and implemented, it crucially speaks about the circumspect, indirect way in which such a space policy is to be developed: "by recommending space objectives to the Member States" (as per Article II(a)) - not by imposing them. The "policies of Member States" (as per Article II(a)) shall be concerted - not be forced in line with any overarching ESA policy 
approach. The truly legal competences allotted to ESA by its Member States through the Convention, finally, remained essentially internal (for instance, to hire personnel and facilities and run them) and contractual (for instance, to spend money on the European space industry to develop certain parts of space hardware, software, or services) in nature (ESA, 1980: Arts. III(3), VI(1), XII, XIV, XV).

ESA's task in the space policy field, as far as the Convention's baseline was concerned, was thus essentially to elaborate and implement whatever could be discerned under the moniker of a European space policy, and to do so by way of undertaking "activities and programmes in the space field" (as per Article II(b)) as well as by "coordinating the European space programme and national programmes, and by integrating the latter progressively and as completely as possible into the European space programme" (as per Article $\mathrm{II}(\mathrm{c})$ ). As for the latter, the reference to "as completely as possible" constitutes an interesting pointer: it should be read "as far as the Member States allow for." The heart of the European space policy as envisaged by the Convention finally was the industrial policy, to which we shall shortly return.

In terms of such programs and activities, at the heart of ESA's existence and role as tool for the elaboration and implementation of any space policies was a two-pronged approach to the space activities conducted by the organization, categorizing them as either "mandatory activities" or "optional activities."

The mandatory activities, mainly addressing basic and scientific activities "on the ground," shall be agreed upon as such by a simple majority of Member States in the ESA Council, the highest organ of the Agency. Once so adopted, they still require all Member States to contribute according to a preset system determining the individual contributions-subject to a two-thirds majority agreeing on the budget (ESA, 1980: Arts. V(1)(a), XI(5)(a), and (5)(e)(ii), XIII(1)). Only in this respect can particular ESA Member States be forced to contribute to a particular program at a predetermined level, but only if a two-thirds majority so agrees; ultimately, ESA is still an intergovernmental organization, meaning an organization composed of sovereign states.

In contrast to mandatory activities, optional activities - which comprise most of the actual space programs and hence over the years average more than 80 percent of ESA's total budget-allow for individual opt-out by Member States not willing to contribute and participate, and at a second level also allow for negotiated (instead of predetermined) levels of contribution for those states not opting out of a particular program (ESA, 1980: Arts. $\mathrm{V}(\mathrm{l})(\mathrm{b}), \mathrm{XI}(5)(\mathrm{c})$ and (5)(e)(ii), XIII(2)). Here, the individual-sovereign discretion of Member States to join a particular ESA program or activity remains supreme; the result being an intricate patchwork of participation. Whatever European Space policy ESA's activities may reflect, the former is not explicit or even required for particular space programs or activities, nor does it determine member state participation therein. Repeatedly, indeed, have Member States chosen to undertake certain space programs outside of the ESA framework, even where involving some other ESA Member States (von der Dunk, 1998: 214-217). ${ }^{9}$

In fact, among the many functions the Council can exercise under the Convention, Article XI does not even refer to the term "space policy." The Director-General (and by inference his staff) can "submit proposals concerning activities and programmes" (ESA, 1980: Art. XII(b)) to the Council, but even if those would stem from a coherent ESA space policy, 
a set of more or less comprehensive and overarching statements setting out general goals and the justification thereof, the adoption of such proposals as either mandatory or optional activities still depends on the Council as just indicated.

The only policy that is further elaborated in the basic legal framework of ESA is the industrial policy, which has to (a) strive for cost-effective use of resources whenever European and/or coordinated national programs are being undertaken; (b) "improve the worldwide competitiveness of European industry"; (c) "ensure that all Member States participate in an equitable manner with regard to their financial contribution"; and (d) "exploit the advantages of free competitive bidding" (ESA, 1980: Art. VII).

As to equitable member state participation, the concept has been famously elaborated by calling for preference, in terms of industry contracted to undertake certain parts of the activities or programs concerned. Such preference pertains, firstly to European industry in general, secondly (in case of an optional activity) to the industry of those Member States participating in that program, and thirdly to the aim of "geographical distribution" and fair return among such Member States, as further elaborated by Annex V to the ESA Convention (von der Dunk, 2015: 219-223; Madders, 1997: 384-398; Lafferranderie, 2005: 107118). ${ }^{10}$ The latter basically tries to guarantee Member States a proportional share of contracts handed out by ESA, ideally for any particular space project but otherwise at least across all projects, as set off against their respective contributions. This system, it should be noted, represents a main reason for the Member States to accept the financial obligations resulting from ESA membership in the first place.

In short: as for ESA, effectively it is assumed there exists something like a European space policy which has come about largely outside of or at least independently from the Convention, for which ESA - to the extent that its Convention provides or allows for that! - may then be used as the most appropriate and effective vehicle to elaborate and implement. If that conclusion is correct, it also means that European space policy at least for the first few decades of Europe's presence in outer space has been little more than the haphazard, organically developed, and largely inarticulate conglomerate of individual national space policies (increasingly often, in contrast, well-articulated) to the extent these contain European cooperative components, more specifically to the extent the relevant Member States are interested or at least willing to use ESA as their preferred vehicle for realization. The characteristics of this organization, as exemplified by its unique legal structure and framework, have given rise to specific forms of institutionalized cooperation with a pragmatic focus, which in turn has largely determined any European space policy to the extent that it, gradually, semi-organically and essentially largely implicitly, could be seen to emerge.

This evaluation stood at least until the European Union started to become substantially involved in space activities in Europe.

\section{The entry of the European Union in the space domain}

The European Union, originating especially from the European Economic Community (EEC) established in the late 1950s (EEC Treaty, 1958), ${ }^{11}$ was primarily focused on legislating and policymaking for the purpose of integration of the liberal market-economies of its 
Member States, that is on promoting free and fair competition as properly balanced with overarching public interests and concerns. Consequently, outer space or space activities did not play any role in its history, law, policies, or activities for the first three decades or so.

In 1986, the Single European Act gave the European Commission considerable competences to fund research and development, as the general European interest in economic progress required increasing technological development-and "space activities" were seen as one area where new key technologies would be developed, and hence were mentioned in the treaty text for the first time (von der Dunk, 2015: 244-245). ${ }^{12}$ Over time, the European Community, then Union, became more involved in certain aspects of space activities because of their increasing commercial relevance and the resulting involvement of private entities in such activities. One prominent example concerned the 1994 Satellite Directive, which following the growing commercialization and privatization of the satellite communications sector kicked off the process toward creating an Internal Market for satellite communication services within the European Union (von der Dunk, 2015: 246-249).13 Another prominent example concerned the 1996 Database Directive that explicitly included remote sensing databases in the sui generis protection accorded to electronic databases (von der Dunk, 2015: 249-250). ${ }^{14}$ In other words, by the very nature of the Union's raison d'etre as a new legal order to some extent replacing the individual national legal orders of its Member States, this institution created binding law regarding certain areas of space activity.

More and more the Union became convinced of the key role space activities could play in enhancing Europe's position in the world, both economically and politically, and of its own role in that context as a key player. In particular, the fragmented approach to a European space policy, if there even was a thing worthy of such a label, was seen to provide an opportunity to enhance the overall European space endeavor-contrary to ESA, the Union could avail itself of binding legal competences, at least as long as either more or less explicitly provided by the founding treaties or more or less explicitly provided by later Directives, Regulations, or Decisions. ${ }^{15}$

Uniquely, the problems and possibilities resulting from the interaction and interference of the two institutions, the Union and ESA, were given shape largely through legal means, whether concerning specific projects such as Galileo and Copernicus, through an overarching Framework Agreement between the two, or through unilateral efforts on the part of the Union as per the aborted Constitutional Treaty and its more successful follow-up, the Treaty of Lisbon.

The approach taken by the European Commission, as the primary protector of European interests and primary policy- and law-initiator, from then on focused on these three main yet interlocked pillars. Taken together, these pillars could be seen as reflecting a growing articulation of some overriding approach to the space arena using (EU) law as a primary driver - in other words, something like a true space policy, in terms of "a plan of action adopted by government[s]" (Heywood, 2007: 426), arose from the competencies that the law, namely the main EU treaties, had allocated to the relevant institutions, notably the Commission.

First, increasingly cooperation was sought with ESA, the other main player regarding integrative efforts of the European space endeavor. Vacillating between recognition of the 
unique expertise which ESA had developed in the technical and operational field and a desire to direct its activities given the Union's broader mandate and much stronger economic and political role, the main result was the 2003 Framework Agreement between the two organizations spelling out the various options for cooperation. ${ }^{16}$

The Agreement prominently called for " $[t]$ he coherent and progressive development of an overall European Space Policy. Specifically, this policy shall seek to link demand for services and applications using space systems in support of the Community policies with the supply of space systems and infrastructure necessary to meet that demand" (Framework Agreement, 2004: Art. 1(1)). The demand side was generally considered to be the Community's, thus Union's domain ${ }^{17}$; ESA was supposed to take care of the supply side as directed by the demand side (von der Dunk, 2015: 253-255). This time, "the overall European Space Policy" (Framework Agreement, 2004: Art. 1(2)(b)) (now prefaced by "the" and in capitals!) was to be "developed," which was more than the elaboration and implementation which so far had taken place through particular programs and activities. The underlying assumption at least with the Commission had been for the European Union to take care of such an "overall European Space Policy," with ESA relegated to ensuring such elaboration and implementation. However, the Agreement fundamentally allowed both organizations to continue doing what they had been doing so far, and even as to their cooperation it provided only an à la carte list of options to cooperate (Framework Agreement, 2004: Arts. 2, 4, 5). In that sense, ESA remained a tool for the implementation of its Member States' national space policies, rather than of any EU-level space policy somehow developed by the Commission as backed by the EU Member States.

Second, the Union took the lead in initiating two European multibillion-euro "flagship projects" in space: Galileo, the European satellite navigation system, and Copernicus, the European earth observation system, taking ESA's expertise to develop the technical and operational aspects of both multisatellite projects in its stride. Both projects were furthermore underpinned not only by EU Resolutions and Declarations (which, being legally speaking nonbinding, essentially were policy documents stating the directions in which the EU future should go, including suggestions for further development by way of strictly legal documents) but also by EU law, binding upon the Member States.18 Galileo, moreover, the older of the two projects, has essentially been brought under EU control ever since the European GNSS ${ }^{19}$ Agency, managing the project, was established as an EU agency under the Commission's jurisdiction. ${ }^{20}$

The policy and legal documents underpinning the two flagship projects provide ample evidence of the Commission's thinking and approach, noting the importance of the two projects for the overall European technological, economic, societal, and political cause. This could well qualify as "European space policies" in the limited domains of satellite navigation respectively satellite earth observation. Yet even then, this would be true only to the extent those policies were backed up by funds to run those projects and by EU law giving the Commission relevant competences, which still required the consent of the Council (meaning, a well-defined majority of EU Member States) and the Parliament as specified by the treaties. ${ }^{21}$ Otherwise, it would amount to little more than recommendations by the Commission to all willing to listen. 
Third, therefore, the Commission started to push for more fundamental powers to drive, if not indeed define, a true European Space Policy. Such a true space policy at the EU level would supersede and guide as relevant any space polices being articulated at national levels (or within ESA for that matter) and, given, the raison d'etre of the European Union, would give rise to ensuing legislation at the EU level to underpin that policy. Initially, the broad political drive for a Constitutional Treaty (2004)22 seemed to provide the ideal vehicle for this ambition. And indeed, the Constitutional Treaty's text provided for a specific competence of the Union to carry out space activities and "define and implement programmes" (as per Article I-14(3)) in that regard, and even more specifically, to "draw up a European space policy" (as per Article III-254(1)) which could give rise to joint initiatives, further support for research and technological development, the coordination of European efforts to explore and exploit outer space, and finally even the initiation of EU law on the issue (Constitutional Treaty, 2004: Art. I-14(3), resp. Art. III-254(1) and (2)). Seemingly, the result was a "space competence" comprising a rather broad set of competences which would really and substantively amount to a European Space Policy respectively a real ability to develop, elaborate, and implement one-were it not for two important caveats.

On the one hand, any space competence thus exercised by the European Union (read its "executive branch," the Commission) "shall not result in Member States being prevented from exercising theirs" (Constitutional Treaty, 2004: Art. I-14(3)). In other words: EU Member States could continue to develop, elaborate, and implement their national space policies (including, if they so wished, by way of ESA and its mechanisms) disregarding, if need be, any European Space Policy enunciated by the Union. Not accidentally, the clause speaks of $a$, not the European space policy, and this moreover once more without capitals.

On the other hand, of course the Constitutional Treaty itself failed. And while its more successful substitute, the Treaty of Lisbon (2009), ${ }^{23}$ largely maintained the clauses on the space competence, ${ }^{24}$ it added one important further catch. The right to initiate EU law on the matter as per the Constitutional Treaty would have been the strongest consequence and symbol of any policy competence and especially important in the European environment with its many institutions, space policies, and national legal regimes. However, precisely that clause was now caveated by the Treaty of Lisbon by the addition "excluding any harmonisation of the laws and regulations of the Member States" (Treaty on the Functioning of the European Union, 2009: Art. 189(2)). Still, nothing prevented individual Member States from not only further developing and implementing their national space policies (again inclusive of ESA, if they so desired) but also from further developing their national laws on the matter. Given that, at the moment of writing, nine EU Member States (Sweden, the United Kingdom, Belgium, the Netherlands, France, Austria, Denmark, Finland, and Greece) have already enacted their own all-encompassing national space laws (Marboe, 2015: 151-166), this can only mean the Union has no real competence here. Any EU-wide national space law (noting that this would not necessarily equate with a European space policy to the extent, in particular, ESA Member States Norway and Switzerland would not be [directly] involved) would by definition require those nine laws, different in many respects, to toe a European line-in other words, be harmonized to comply with the EU model. 


\section{A true European space policy?}

The question remains what this key clause of the Treaty of Lisbon on the space competence essentially has come to mean in terms of European space policy and of any European space law required to provide that policy with a solid, common, and effective foundation and toolbox for elaboration and implementation.

It should be clear, first, that any European space policy referenced so far by the documents discussed above would also in the context of the European Union amount to a slightly abstract and largely strategic formulation of overarching goals and objectives, which may at some point be given shape by specific law or regulation-but are equally often given shape by nonlegal, essentially political and policy instruments. Its lack of exclusivity as "the" European space policy still goes back to the unwillingness of the EU Member States in toto to hand over their political and policy-making authority, which specifically as to law-making authority then was enshrined in the principles of "subsidiarity" and "proportionality" (Treaty on the Functioning of the European Union, 2009: Art. 5) requiring careful and explicit legitimization of any EU-level legislative action as compared to leaving it for the individual Member States to regulate.

Thus, the recognition of an EU competence to draft an overarching space policy can be seen as merely the initial recognition that any further legislative initiatives on matters of space and space activities, firstly, at the EU level should not be dismissed off-hand and secondly, as far as still possible at the individual Member State level, should essentially fit within the broad framework of such a policy.

Second, the Union's competence, for the purpose of the aforementioned space policy, was spelled out as an authority to "promote joint initiatives, support research and technological development, and coordinate the efforts needed for the exploration and exploitation of space" (Treaty on the Functioning of the European Union, 2009: Art. 189(1)). Indeed, such programs and activities would be manifestations of a space policy at a more concrete and less overarching level, thus reinforcing the conclusion that by obtaining the competence to draft (a) European space policy, the EU institutions have actually prepared the ground for truly legislative initiatives, rather than as such taking them. That is essentially policy, not law-yet hugely important for the legal realm, and thereby amounting to an embryonic European space policy indeed.

The legitimacy of the Union to promote-including, most notably, by means of its budget-such joint initiatives, research and development, and general coordinating activities now no longer depends upon a specific market-related need or requirement but would in principle be broadly accepted across the spectrum of space activities and applications. This, so far, without addressing the legal aspects of policy elaboration and implementation with a view to subsidiarity and proportionality, which arguably are at least as important as the funding aspects thereof.

Third, however, this is where another aspect of the space competence comes into play. In addition to the foregoing, the EU institutions may now also "establish the necessary measures, which may take the form of a European space program" (Treaty on the Functioning of the European Union, 2009: Art. 189(2)). Such measures, definitively, would include legal ones, if indeed considered "necessary." Compare this to the decades when ESA 
was the main embodiment of any European space policy. The reference in the Treaty of Lisbon to space programs developed by the Union in the context of a space policy and supported, as necessary, by specific legal measures established pursuant to "the ordinary legislative procedure" (Treaty on the Functioning of the European Union, 2009: Art. 294) is considerably more coherent, and by that token makes such an "EU space policy" more effective and relevant. It also clearly points to major space programs (of which Galileo and Copernicus were already examples) as accompanied by the necessary legal framework, or even to legal measures considered desirable or necessary, again properly taking subsidiarity and proportionality into due account.

By way of those clauses, therefore, effectively the competence of the EU institutions to draft a European space policy to those extents has now been more or less silently acknowledged, in particular to the extent such a policy would tie in with the general remit of the EU institutions to further the economic and societal development of the Member States within an ever more coherent Union (Treaty on the Functioning of the European Union 2009, Preamble). From this perspective the competence of the Union to now (also) develop and implement European space programs as per the Treaty of Lisbon is an extension of the "politico-programmatic" competences of the EU institutions as relative to those of EU Member State authorities for projects specifically agreed upon and underpinned by relevant EU law such as Galileo and Copernicus.

Its adjacent competence to establish the necessary legal measures finally gives any such European space policy developed within the bosom of the Union the teeth to make a real difference in the European space environment. This competence would no longer be completely dependent on sector-specific characteristics related to commercial markets and require application of the free market and competition principles relatively narrowly focused on a free and level playing field for commercial enterprise throughout the Union. This had happened, of course, most elaborately in the satellite communications sector. There indeed, the Commission essentially had set about harmonizing market access, state aid, and licensing issues all in as far as distorting the Internal Market, only now and then inserting clauses protecting wider public interests, such as public or universal services.

The above analysis might seem to point at only one conclusion: the European Union has now been formally charged with so many specific mandates, tasks, and competences that it most certainly can develop and implement $a$ European space policy. But can it develop and implement the European space policy? In other words: what value has $a$ European space policy developed by the Union if other key players in Europe-notably the major spacefaring nations, Germany, France, the United Kingdom (even more so of course in view of any impending Brexit), Italy and perhaps some others - remain at liberty to develop their own space laws, policies, strategies, programs, and projects? What value does it have if even for cooperative efforts within Europe they do not need to engage the Union's organs and machinery, and can either go bilaterally or multilaterally outside of the EU framework and/or continue using the ESA framework?

This is where the-for many disappointing-clause of Article 189(2), which conditions the EU space competence by "excluding any harmonization of the laws and regulations of the Member States" comes in. There is no way around this; space remains fundamentally different from other areas. In other areas, following subsidiarity and proportionality 
individual Member States would no longer be entitled to draft their own legislation to the extent those competences had been transferred to the EU level and such transfer would ipso facto allow the EU institutions to guarantee a harmonized regime, if necessary, by harmonizing existing national regimes. When it comes to space, however, such harmonization is not permissible, and the Union has to stay away from legislative efforts in any realm already regulated by the-or at least some-Member States.

By inference, any European space policy which is bereft of legal instruments as a consequence of this clause, is very much a "paper tiger": wherever and to the extent that Member States have already elaborated relevant domestic law on an issue of space activities, the Union basically has to step back. The most prominent example thereof concerns private space activities, the very core of the Union's existence, legitimacy, and role from the beginning, and making sure that the licensing thereof is largely harmonized to establish a level playing field. With so far, as mentioned, nine EU Member States having established a national space law providing in any appreciable detail for a licensing system, the aforementioned clause effectively excludes a competence for the Union to try to harmonize those licensing requirements. Whatever European space law it could dictate, it would not include any effort to direct the EU Member States to change their national space laws and licensing regimes so as to adhere to a more uniform standard.

\section{Concluding remarks}

Reverting back to the research questions introduced earlier on, the legal analysis above does not allow for any major conclusions on the contribution of space policy to European identity formation and the integration process. Space policy in fact is a derivative of the broader integration processes, for specific reasons of efficiency and increase of knowledge as far as the participating European states are concerned and further boosted-but only as far as their respective, legally circumscribed mandates allow for-by the two principal European institutions acting in space, the European Space Agency and the European Union. Tellingly, however, though almost all astronauts from (Western-) European countries have legally speaking flown as "ESA astronauts," national sentiments still refer to them as national heroes.

As for the interests of EU and ESA Member States and institutions in space, these have by contrast hugely benefited from the two institutional frameworks and, in the case of the Union, also the competencies in the legal area. While strictly speaking the Member States were the ultimate deciders, the core role of the two institutions has been able to drive European space efforts forward likely much more than it would have been possible to do in their absence, in particular in the case of ESA. The extent to which this general process was reflective of and/or driven by a true European space policy, however, may be doubted, as discussed: it was seen to operate much more in the realm of implementation, elaboration, and semi-organic development than in the realm of conscious, overarching policy definition.

Efforts to take more centralized control over space policy and policies in the context of Europe, therefore, could only go so far. ESA and the Union used "space" and its general benefits to society and economy as much as they could to both drive the European space effort forward and themselves obtain leadership roles in that regard, but as analyzed, the 
results were rather mixed. Even in the case of the Union, the individual sovereignty of the Member States ultimately continues to prevail. While some inroads were made to an Internal Market in commercial space services (notably in the realm of satellite communications) and the inherent global character of sustainable development and foreign policy allowed the Union to make some progress in those realms as well, the legal limitations provided by the treaties, including even the Treaty of Lisbon, determined the extent to which it was allowed to do so.

While thus the impact of those two institutions in particular on the development of the European space endeavor as a whole is undeniable and important, at times even impressive; whether that amounts to a true European policy replacing a conglomerate of national and international space policies concocted in national capitals, Brussels (for the Union) and Paris (for ESA) remains questionable. Whether in turn that allows for further insight into the relevance of neo-institutionalism as an effort to explain the development of the European space endeavor, policy and/or policies is even more questionable, given that "neoinstitutionalism" has been characterized as "fall[ing] well short of a comprehensive theory," as a "hallmark" among other hallmarks, "has major gaps in its self-conception" and in the end is mainly "fully aware of what it is not" (Hoerber and Lieberman, 2019: 5-6).

\section{Notes}

1. While increasingly "Europe" is used as shorthand for "the European Union," that of course does injustice to the considerable number of countries definitively European in terms of geography, history, and culture yet for one reason or another not part of the Union. In this chapter, "Europe" will therefore, unless clearly indicated otherwise, refer to the geographical area stretching out between the Arctic and the Mediterranean, and between the Atlantic Ocean to the Ural Mountains. Definition by Hoerber (2006: 324).

2. Art. 38(1)(A) and (b), Statute of the International Court of Justice, San Francisco, done 26 June 1945, entered into force 24 October 1945; 156 UNTS 77; USTS 993; 59 Stat. 1031; UKTS 1946 No. 67; ATS 1945 No. 1; is generally considered to reflect the sources of public international law, first and foremost "international treaties" and "international custom, as evidence of a general practice accepted as law."

3. Note, for instance, that Australia, of major interest to the ELDO Member States because of its launch facilities, became an associate member of that organization - not a full one.

4. By way of the Convention for the Establishment of a European Space Agency (hereafter ESA Convention), Paris, done 30 May 1975, entered into force 30 October 1980; 1297 UNTS 161; UKTS 1981 No. 30; Cmnd. 8200; 14 ILM 864 (1975); Space Law - Basic Legal Documents, C.I.1.

5. As per the Convention Establishing the European Telecommunications Satellite Organization (EUTELSAT) (hereafter EUTELSAT Convention), Paris, done 15 July 1982, entered into force 1 September 1985; UKTS 1990 No. 15; Cm. 956; Cmnd. 9069; Space Law-Basic Legal Documents, C.II.1; and the Operating Agreement Relating to the European Telecommunications Satellite Organization (EUTELSAT) (hereafter EUTELSAT Operating Agreement), Paris, done 15 July 1982, entered into force 1 September 1985; UKTS 1990 No. 15; Cm. 956; Cmnd. 9154; Space Law-Basic Legal Documents, C.II.2. 
6. As per the Convention for the Establishment or a European Organization for the Exploitation of Meteorological Satellites (EUMETSAT) (hereafter EUMETSAT Convention), Geneva, done 24 May 1983, entered into force 19 June 1986; 1434 UNTS 3.

7. The WEU had been established by the Paris Agreements amending the Brussels Treaty, Paris, done 23 October 1954, entered into force 5 May 1955; 211 UNTS 342; UKTS 39 (1955) Cmd. 9498.

8. It is an oft-repeated misunderstanding that Canada is also a Member State of the European Space Agency - it is not. Instead, it has a long-term Cooperating Agreement with ESA and sits at the table at ESA Council meetings as Cooperating Partner-only for agenda items in which it is actually involved. Thus, Canada for instance also has no voting rights, nor obligations to contribute financially to the overheads and other general costs of running the Agency; its financial and other contributions as well as relevant obligations in relation to specific projects are agreed upon per project.

9. One example concerns the SPOT satellite system for Earth observation, which was a French project with minor participation, at various stages, of three other ESA Member States: Belgium, Sweden, and Italy.

10. See Art. VII(c), ESA Convention; Arts. II, IV, Annex V to the ESA Convention.

11. As per the Treaty of Rome, or Treaty establishing the European Economic Community (hereafter EEC Treaty), Rome, done 25 March 1957, entered into force 1 January 1958; 298 UNTS 11.

12. Pursuant to Art. 24, Single European Act, Luxembourg/The Hague, done 17/28 February 1986, entered into force 1 July 1987; UKTS 1988 No. 31; Cm. 372; OJ L 169/1 (1987); 25 ILM 506 (1986); new clauses were added to the then-EEC Treaty providing for the relevant new competences of the Commission.

13. Commission Directive amending Directive 88/301/EEC and Directive 90/388/EEC in particular with regard to satellite communications, 94/46/EC, of 13 October 1994; OJ L 268/15 (1994).

14. Directive of the European Parliament and of the Council on the legal protection of databases, 96/9/EC, of 11 March 1996; OJ L 77/20 (1996).

15. Note that those forms of EU law still had to go through a very complicated process of legislation, involving various majorities within the Commission, the Council of Ministers representing the Member States and the European Parliament, but by and large offered considerable opportunities to impose EU law also on individual states opposed to such law.

16. Framework Agreement Between the European Community and the European Space Agency (hereafter Framework Agreement), Brussels, done 25 November 2003, entered into force 28 May 2004; OJ L 261/64 (2004).

17. Note that the quote refers to Community, seen as the operative part of the Union; however, for precisely that reason in this context what accrued to the Community accrued to the Union as opposed to (for example) remaining with the individual Member States.

18. Cf., e.g., for Galileo, Regulation of the European Parliament and of the Council on the implementation and exploitation of European satellite navigation systems and repealing Council Regulation (EC) No. 876/2002 and Regulation (EC) No. 683/2008 of the European Parliament and of the Council, No. 1285/2013/EU, of 11 December 2013; OJ L 347/1 (2013); for Copernicus, Commission Delegated Regulation supplementing Regulation (EU) No. 911/2010 of the European Parliament and of the Council on the European Earth monitoring programme (GMES) by establishing registration and licensing conditions for GMES users and defining criteria for restricting access to GMES dedicated data and GMES service information, No. 1159/2013/EU, of 12 July 2013; OJ L 309/1 (2013). 
19. GNSS stands for "Global Navigation Satellite Systems"; in effect, this largely focused on the European GNSS systems EGNOS and Galileo.

20. The European GNSS Agency was established (as the European GNSS Supervisory Authority) by Council Regulation on the establishment of structures for the management of the European satellite radio-navigation programs, No. 1321/2004/EC, of 12 July 2004; OJ L 246/1 (2004); the first piece of EU law on the subject of satellite navigation.

21. See in particular Arts. 293-299, Treaty establishing the European Community as amended by the Treaty of Lisbon amending the Treaty on European Union and the Treaty establishing the European Community (hereafter Treaty on the Functioning of the European Union), Lisbon, done 13 December 2007, entered into force 1 December 2009; OJ C 326/47 (2012).

22. Treaty establishing a Constitution for Europe (hereafter Constitutional Treaty), Rome, done 29 October 2004, not entered into force; OJ C 310/1 (2004).

23. Treaty of Lisbon amending the Treaty on European Union and the Treaty establishing the European Community (hereafter Treaty of Lisbon), Lisbon, done 13 December 2007, entered into force 1 December 2009; OJ C 306/1 (2007).

24. Art. 4(3), Treaty of Lisbon, copies Art. I-14, Constitutional Treaty; Art. III-254, Constitutional Treaty, translated into Art. 189, Treaty on the Functioning of the European Union.

\section{Bibliography}

Cambridge Dictionary. (2018) https://dictionary.cambridge.org/dictionary/english/policy. Accessed 14 January 2018.

Cassese, A. (2001) International Law, Oxford: Oxford University Press.

Constitutional Treaty. (2004) Treaty Establishing a Constitution for Europe, Rome, done October 29, not entered into force; OJ C 310/1.

Daviter, F. (2011) Policy Framing in the European Union, Basingstoke: Pal grave Macmillan.

Delanty, G., and Rumford, C. (2013) Rethinking Europe: Social Theory and the Implications of Europeanization, London: Routledge.

EEC Treaty. (1958) Treaty of Rome or Treaty Establishing the European Economic Community, Rome, done March 25, 1957, entered into force January 1, 1958; 298 UNTS 11.

ELDO. (1964) Convention for the Establishment of a European Organization for the Development and Construction of Space Vehicle Launchers, London, done March 29, 1962, entered into force February 29, 1964, expired October 30, 1980; 507 UNTS 177; UKTS 1964 No. 30; Crnnd. 2391; ATS 1964 No. 6.

ESA. (1980) Convention and Council Rules, ESA Communications, Noordwijk, 1297 UNTS 161; UKTS 1981 No. 30; Cmnd. 8200; 14 ILM 864 (1975); Space Law - Basic Legal Documents, C.I.I.

ESRO. (1964) Convention for the Establishment of a European Space Research Organization, Paris, done June 14, 1962, entered into force March 20, 1964, expired October 30, 1980; 158 UNTS 35: UKTS 1964 No. 56; Cmnd. 2489.

Framework Agreement. (2004) Framework Agreement Between the European Community and the European Space Agency, Brussels, done November 25, 2003, entered into force May 28, 2004; OJ L 261/64.

Hasse, R., and Krücken, G. (1999) Neo-Institutionalism, Bielefeld: Transcript Publishers.

Heywood, A. (2007) Politics (3rd edition), Basingstoke: Palgrave Macmillan. 
Hobe, S., Hofmannová, M., and Wouters, J. (eds.) (2011) A Coherent European Procurement Law and Policy for the Space Sector, Berlin: Lit Verlag.

Hobe, S., Schmidt-Tedd, B., and Schrogl, K-U. (eds.) (2006) "Project 2001 Plus" - Global and European Challenges for Air and Space Law at the Edge of the 21st Century, in: Schriften zum Luftund Weltraumrecht, Cologne: Carl Heymanns Verlag.

Hoerber, T. (2006) The Foundations of Europe, Wiesbaden: VS-Verlag.

Hoerber, T., and Lieberman, S. (2019) A European Space Policy-Past Consolidation, Present Challenges and Future Perspectives, London: Routledge.

Hoerber, T., and Stephenson, P.(2016) European Space Policy - European Integratlion and the Final Frontier, London: Routledge.

JO. (1961) "Statut du Centre National d'Etudes Spatiales; Loi nº 61-1382 du 19 décembre 1961," Joumal Officiel de la République Française, 11665, December 20.

Krige, J., Russo, A., and Sebasta, L. (2000) A History of the European Space Agency 1958-1987, Vol. I, the Story of ESRO and ELDO 1958-1973, Noordwijk: ESA Publications Division.

Lafferranderie, G. (2005) European Space Agency, International Organizations-Suppl. 20, The Hague: Kluwer Law International.

Lepard, B. D. (ed.) (2017) "Introduction," in: Reexamining Customary International Law, Cambridge: Cambridge University Press, pp. 1-46.

Madders, K. (1997) A New Force at a New Frontier, Europe's Development in the Space Field in the Light of Its Main Actors, Politics, Law and Its Activities from the Beginning to the Present, Cambridge: Cambridge University Press.

Malanczuk, P. (1997) “Actors: States, International Organisations, Private Entities," in: Lafferranderie, G., and Crowther, D. (eds.) Outlook on Space Law Over the Next 30 Years, The Hague: Kluwer Law International, pp. 23-36.

Mantl, L. (2011) "The European Union," in: Brünner, C., and Soucek, A. (eds.) Outer Space in Society, Politics and Law, Vienna: Springer, pp. 406-438.

Marboe, I. (ed.) (2012) Soft Law in Outer Space-The Function of Non-Binding Norms in International Space Law, Vienna: Böhlau Verlag.

Marboe, I. (2015) “National Space Law," in: von der Dunk, F., and Tronchetti, F. (eds.) Handbook of Space Law, Cheltenham: Edward Elgar, pp. 127-204.

March, J., and Olsen, J. ( 1989) Rediscovering Institutions: The Organisational Basis of Politics, London: Collier Macmillan.

Senge, K. (2006) "Zum Begriff der Institution im Neo-Institutionalismus," in: Senge, K., and Hellmann, K-U. (eds.) (2006) Einführung in den Neo-Institutionalismus - Introduction to Neo-Institutionalism, Wiesbaden: VS-Verlag, pp. 35-47.

Senge, K., and Hellmann, K-U. (2006) Einführung in den Neo-Institutionalismus (Introduction to NeoInstitutionalism), Wiesbaden: VS Verlag.

Suzuki, K. (2003) Policy Logics and Institutions of European Space Collaboration, Abingdon: Ashgate.

Treaty on the Functioning of the European Union (TFEU). (2009) Treaty Establishing the European Community as Amended by the Treaty of Lisbon Amending the Treaty on European Union and the Treaty Establishing the European Community, Lisbon, done December 13, 2007, entered into force December 1, 2009; OJ C 326/47 (2012).

Van de Wouwer, J. L., and Lambert, F. (2008) European Trajectories in Space Law, Brussels: Bruylant.

von der Dunk, F. G. (1998) Private Enterprise and Public Interest in the European "Spacescape," Leiden: Leiden University. 
von der Dunk, F. G. (2010) “Europe and Security Issues in Space: The Institutional Setting,” Space and Defense (4): 71-99.

von der Dunk, F. G. (ed.) (2011) National Space Legislation in Europe, Leiden: Brill Pub.

von der Dunk, F. G. (2015) “European Space Law," in: von der Dunk, F., and Tronchetti, F. (eds.) Handbook of Space Law, Cheltenham: Edward Elgar, pp. 205-268.

Wallace, H., Pollack, M. A., and Young, A. R. (2010) Policy-Making in the European Union, Basingstoke: Palgrave Macmillan.

Wallace, R. M. M. (1997) International Law, London: Sweet and Maxwell. 